Pregledni znanstveni rad

DOI: $10.17234 /$ Croatica.42.14

UDK: $81 ' 362$

811.163.42’367.633:811.161'367.633

Primljen: 7. XII. 2017.

Prihvaćen: 9. II. 2018.

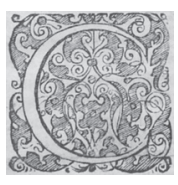

\title{
PRIJEDLOZI TVORENI S IZ- / ИЗ- U HRVATSKOM I RUSKOM JEZIKU
}

\author{
Ivana Matas Ivanković \\ Institut za hrvatski jezik i jezikoslovlje \\ imatas@ihjj.hr
}

U radu se obrađuju hrvatski i ruski prijedlozi tvoreni od dvaju prijedloga od kojih je na prvome mjestu iz- / u3-. U hrvatskome su to iskraj, ispod, ispred, isred, iza, izmedu, iznad, iznutra, izvan, izviše. Popis takvih prijedloga koji se obično navode u ruskim gramatikama i rječnicima proširen je u monografiji Vsevolodove, Kukuškine i Polikarpova posvećenoj prijedlozima te se uz из-за і из-под obrađuju još і извне, извнутри, иззади, из-меж, из-между, из-над, изнутри, из-перед, из-промеж, из-промежду, из среди. Riječ је о novijim tendencijama u jeziku, što pokazuju i primjeri iz korpusa, te među njima postoje razlike u načinu zapisa, ali i u gramatičkim obilježjima. Prijedlozi s toga popisa pravopisno su, tvorbeno i gramatički uspoređeni s hrvatskim prijedlozima.

Ključne riječi: prijedlozi, hrvatski jezik, ruski jezik, genitiv, instrumental

\section{UVOD}

Prijedlozi su po tvorbi heterogena skupina. Primarni su prijedlozi neproizvedeni ( od, do, na...), dok se ostali svojim oblikom podudaraju s oblikom koje druge vrste riječi (blizu, koncem, glede...) ili u sastavu imaju više riječi te se pišu sastavljeno (poviše, uoči...) ili nesastavljeno (na kraju, s obzirom na...). U ovom radu obrađuju se hrvatski prijedlozi koji u sastavu imaju dva prijedloga, od kojih je prvi iz- (kao što su ispod, iznad, izvan i dr.) te se 
uspoređuju s ruskim prijedlozima nastalima po istome tvorbenom modelu (kao što su из-за, из-под te извне, иззади, из-перед i dr.). ${ }^{1}$ Budući da jezici u tom dijelu pokazuju sličnosti, ali i razlike, proučit će se pravopisna, tvorbena i gramatička obilježja ove skupine prijedloga. Iako je u hrvatskome riječ o deset prijedloga, a u ruskome o trinaest, nisu svi jednako učestali i ne pripadaju istom registru, ali su zbog svojih obilježja zanimljivi, pogotovo $\mathrm{s}$ obzirom na to da neki od njih donedavno uopće nisu bili zastupljeni u literaturi. U radu su upotrijebljeni hrvatski korpus $h r W a C 2.2$ i ruski korpus ruTenTen11, pregledavani na https://the.sketchengine.co.uk/auth/corpora/. Riječ je o mrežnim korpusima koji su uzeti zbog svoje veličine ( $h r W a C$ sadržava gotovo 1,4 milijarde pojavnica, a ruTenTen 11 više od 18 milijardi pojavnica), zbog toga što su pretraživi na isti način te zbog toga što imaju stilski raznovrsne tekstove prikupljene iz različitih izvora (novinski portali, mrežne stranice službenih organizacija...), od kojih neki pripadaju izravnoj komunikaciji (forumi) te daju uvid u jezik svakodnevne, obične upotrebe.

U hrvatskim gramatikama od prijedloga tvorenih s $i z$ - obično se navode ispod, ispred, iza, između, iznad, izvan (usp. primjerice Barić i sur. 1997; Raguž 1997; Silić i Pranjković 2007). U rječnicima se navodi još i iskraj koji je obilježen kao prilog iako je iz primjera ili opisa vidljivo da je riječ o

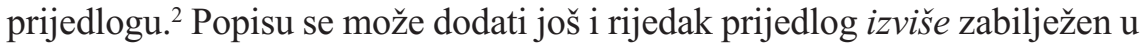
jednom primjeru iz korpusa: "Donijeh nešto izviše jela", iz Isušene kaljuže Janka Polića Kamova.

Ruska gramatika (1982) i Kratka ruska gramatika (2002) od prijedloga tvorenih s uз- navode uз-за i из-nод. U rječnicima se osim njih nalaze još i извне, ali samo kao prilog, te изнутри, koji Ožegov određuje kao prilog i kao prijedlog, ${ }^{3}$ a Kuznjecov samo kao prilog. No teorijska istraživanja u ruskome proširila su taj popis te Vsevolodova, Kukuškina i Polikarpov

\footnotetext{
Prijedlozi iskraj, ispod, ispred, između, iznad, izvan, izviše te ruski из-nод i из-за iz drugačije perspektive obrađeni su u knjizi Izražavanje prostora $i$ vremena prijedlozima s genitivom $u$ hrvatskom i ruskom jeziku, kojoj je recenzent bio prof. Ivo Pranjković. Knjiga je proširena verzija doktorata Prijedlozi s genitivom u hrvatskom i ruskom jeziku, kojemu je mentor bio također prof. Ivo Pranjković te mu i ovom prilikom zahvaljujem.

2 U Anićevu rječniku i na $H J P$-u navodi se i upotrebna oznaka da je rijetko: "pril. rij. 1. v. pokraj 2. v. skraja". VRH ga također opisuje kao prilog s odrednicom "RAZG 1. $\rightarrow$ pokraj (1 a) [Tako i oni iskraj njega, pobuniše se na njega] 2. $\rightarrow$ skraja [iskraj prošloga stoljeća]".

3 “1. нареч. С внутренней стороны, из внутренней части чего-н. Дверь заперта и. Крики доносятся и. 2. чего, предлог с род. п. Из чего-н., из внутренней части чего-н. Пробоина и. трюма."
} 
u svojoj monografiji Русские предлоги и средства предложного типа (2014) obrađuju još: извне, извнутри, иззади, из-меж, из-между, из-над, из-перед, из-промеж, из-промежду, из среди. Ti se prijedlozi međusobno razlikuju po načinu zapisa, ${ }^{4}$ ali i po rekcijskim obilježjima. Primjeri koje autori uz njih navode uglavnom su preuzeti s interneta, a neki od njih nemaju potvrde ni u Nacionalnom korpusu ruskog jezika (http://www.ruscorpora. ru/index.html), što, uz činjenicu da dosad nisu zabilježeni u gramatikama i rječnicima, pokazuje da je riječ o pojavi koju tek treba detaljno istražiti.

Većina ruskih prijedloga ima svoj tvorbeni ekvivalent u hrvatskome. Iako nije zabilježen u hrvatskim gramatikama i rječnicima, isred je zastarjeli prijedlog, ekvivalent ruskom uз сред $u^{5}$, koji se u korpusu pojavljuje uglavnom u sakralnim tekstovima: "Je li ikad koji narod čuo glas Boga gdje govori isred ognja kao što si ti čuo i na životu ostao?; Glavar njihov iz njih će niknuti, vladar njihov isred njih će izaći."

Ruskome извнутри ${ }^{6}$, изнутри ${ }^{7}$ ekvivalent je hrvatski iznutra koji je u rječnicima određen samo kao prilog (usp. RHJ, HJP), no ciljana pretraga po korpusu, kojom se tražio oblik u genitivu iza iznutra, ${ }^{8}$ dala je i primjere u kojima iznutra uvjetuje oblik riječi iza sebe te ima obilježja prijedloga, npr.: "[...] ali možda je ta molitva iznutra teatra put da se Isus vrati..."; "Naime, idejom suverenosti trebala se osigurati sigurnost i mir, kako izvana tako i iznutra države."

Ruski иззади nema ekvivalenta u hrvatskome, a od hrvatskih prijedloga iskraj i izviše nemaju ekvivalenta u ruskome.

${ }^{4}$ U ovome radu prijedlozi su zapisani u skladu s prevladavajućim brojem potvrda za određeni zapis u korpusu ruTenTen11.

5 Usp. primjere "Господь на Хориве говорил к вам из среди огня." "Gospodin na Horebu (Sinaju) govorio vam je isred ognja."; "Их ассортимент чрезвычайно широк и из среди них действительно есть что выбрать." "Njihov asortiman iznimno je širok i među njima zasigurno se ima što odabrati." U ovom i ostalim prijevodima primjera slijedi se što je više moguće struktura izvorne rečenice.

6 Usp. primjer "[...] революционер по нынешним временам больше сделает извнутри России...” "[...] revolucionar će u današnjim vremenima više napraviti iznutra Rusije..."

7 Usp. primjer "Мягкая синтетическая пряжа прилегает к телу изнутри ткани..." "Meka sintetička pređa prianja uz tijelo iznutra tkanine..."

8 U pretrazi je u polje CQL upisan regularni izraz [lemma="iznutra"][tag="....g"], što je kao rezultat dalo 81 primjer. 


\section{PRAVOPISNA OBILJEŽJA PRIJEDLOGA S IZ- / ИЗ-}

Različiti zapisi ovih prijedloga pokazuju i razlike u pravopisima hrvatskog i ruskog jezika. Hrvatski je pravopis fonološki s morfonološkim elementima. Fonološki je jer je utemeljen na glasovnome načelu (piše se npr. bežični, otpasti, svadba). Morfonološko načelo primjenjuje se kada se čuva glasovni sastav tvorbenih sastavnica tako da se ne bilježe glasovne promjene na morfemskoj granici (piše se npr. gradski, pedesettrećina, podcijeniti) (usp. Hrvatski pravopis 2013: VII). Ruski je pravopis zasnovan na morfološko-etimološkom načelu, tj. isti morfološki elementi riječi (npr. korijen, prefiks), neovisno o tome što se izgovaraju drukčije, pišu se jednako (usp. Poljanec 2013: 214) (iako i u ruskome postoje iznimke od toga pravila, usp. безчастный-бессовестный).

U hrvatskim prijedlozima tvorenima s $i z$ - dolazi do obezvučenja kada drugi prijedlog počinje bezvučnim suglasnikom i ta se glasovna promjena bilježi i u pismu (ispod, ispred), u ruskome se to obezvučenje ne bilježi u pismu (из-перед, из-под, из-промеж). Isto tako u hrvatskome dolazi do ispadanja suglasnika kada se dva ista suglasnika nađu jedan do drugoga, dok se u ruskome to ne događa (usp. hrvatski $i z a$ i ruski $u з-3 a$, gdje su sačuvana oba tvorbena elementa i granica među njima).

U ruskome jeziku složeni prijedlozi ovoga tipa trebali bi se zapisivati sa spojnicom, ${ }^{9}$ no prijedlozi koje navode Vsevolodova, Kukuškina i Polikarpov (извне, иззади, из-между, из-над, из среди) nisu zapisani na jednak način te neki od njih nisu u skladu s navedenim pravilom. Zapis je provjeren $\mathrm{i}$ u korpusu ruTenTen 11: pokazalo se da većina njih može biti zapisana na tri različita načina: sastavljeno ("Никакого раскаяния изза избиения любовника она не испытывала..." "Nikakva kajanja zbog tuče ljubavnika nije osjećala...”), sa spojnicom (“На мой взгляд, это из-за отсутствия целей." "Ро mojemu mišljenju, to je zbog nedostatka ciljeva.") i kao dvije riječi ("Из за того что отвык от него уже, было сложно..." "Zbog toga što sam se već odviknuo od njega, bilo je složeno."). U Tablici 1. prikazani su brojevi potvrda dobiveni pregledom korpusa. Dominantan zapis označen je podebljano. Kod najviše prijedloga dominira nesastavljeni zapis (npr. uз среди, из меж, из перед), kod nekih dominira spojeni zapis (npr. извне,

9 “Сложные предлоги из-за, из-под, по-за, по-над, по-под, с-под, для-ради, за-ради пишутся через дефис, например: из-за стола, из-под шкафа, спрятался по-за корчму...” (Rozentalj http://rosental-book.ru/ortho_xv.html\#sect60, pristupljeno 17. studenoga 2017). 
извнутри), dok su из-за і из-под u najvećem broju primjera zabilježeni sa spojnicom (a to je i u skladu s pravopisnim pravilom).

Tablica 1. Zapis ruskih riječi i izraza s $и з$ - prema korpusu (nije napravljena filtracija priložne i prijedložne upotrebe).

\begin{tabular}{lrrr}
\hline & rastavljeno & sa spojnicom & sastavljeno \\
\hline из среди & $\mathbf{1 4 0}$ & 2 & (исреди) 18 \\
извне & 7129 & 359 & $\mathbf{1 2 8} \mathbf{7 6 2}$ \\
извнутри & 302 & 12 & $\mathbf{3 9 1}$ \\
из-за & 137573 & $\mathbf{3 9 8 7} \mathbf{0 0 6}$ & 52222 \\
иззади & 1 & 1 & $\mathbf{4}$ \\
из меж & $\mathbf{3 7}$ & 1 & 0 \\
из между & $\mathbf{1 4 4}$ & 4 & 64 \\
из над & $\mathbf{1 7 2}$ & 6 & 0 \\
изнутри & 1964 & 48 & $\mathbf{2 5 6} \mathbf{7 2 3}$ \\
из перед & $\mathbf{2 1 3}$ & 30 & 0 \\
из-под & 8549 & $\mathbf{3 8 9 7 5}$ & 9948 \\
из промеж & $\mathbf{2}$ & 1 & 1 \\
из промежду & $\mathbf{3}$ & 0 & 0 \\
\hline
\end{tabular}

Odstupanja od pravilom predviđenog zapisa mogla bi se promatrati i kao posljedica analize na mrežnom korpusu, u kojem su u većem dijelu nego u Nacionalnom korpusu ruskog jezika zastupljeni pisanorazgovorni oblici, ${ }^{10}$ no prijedložna funkcija takvih riječi ili izraza koji nisu zabilježeni u gramatikama i rječnicima te neujednačenosti u zapisu potvrđuju da je riječ o pojavi u ruskom jeziku koja (još) nije postala dijelom sustava. S obzirom na to da je u hrvatskome veći broj prijedloga iz ove skupine koji su već zabilježeni u gramatikama i rječnicima nego što je to u ruskome, kolebanja u njihovu zapisu gotovo da i nema. Moguća tendencija daljnjeg spajanja prijedloga $i z \mathrm{~s}$ nekim drugim prijedlogom u hrvatskome provjerena je u korpusu, pri čemu su se tražili primjeri u kojima neposredno za prijedlogom $i z$ dolazi drugi

${ }^{10}$ Ipak, valja istaknuti da su i u Nacionalnom korpusu zabilježeni primjeri koji nisu u skladu s pravopisnim pravilom, primjerice uz 25161 primjer za из-под koji je u skladu s pravopisom nalazi se i 486 primjera s nesastavljenim zapisom - npr. “[...] ничего не понимал из того, что бормочет этот ужасный, из под земли выскочивший эксперт...” “[...] ništa nije shvaćao od toga što mrmlja taj užasni ekspert koji je iskočio ispod zemlje." 
prijedlog. ${ }^{11} \mathrm{U}$ Tablici 2. prikazano je prvih 10 rezultata pretrage $\mathrm{u} \mathrm{hrWaC}$-u, poredanih po učestalosti te broj potvrda.

Tablica 2. Prijedlog iz za kojim slijedi drugi prijedlog

\begin{tabular}{rlr}
\hline 1. & iz preko & 308 \\
2. & iz iz & 298 \\
3. & iz za & 293 \\
4. & iz u & 174 \\
5. & iz do & 149 \\
6. & iz prije & 90 \\
7. & iz na & 89 \\
8. & iz zbog & 85 \\
9. & iz po & 84 \\
10. & iz S & 75 \\
\hline
\end{tabular}

Kod udvojenih primjera s $i z$ iz riječ je očito o pogrešci u korpusu (usp. "Izvadite iz iz folije i ostavite da se ohlade."), dok je u ostalim primjerima riječ o okazionalnim vezama (kada nakon $i z$ dolazi sintagma koja počinje prijedlogom) koje nemaju tendenciju prelaska u novi prijedlog sraslicu jer prijedlozi međusobno nisu povezani, već su se u redu riječi slučajno našli jedan pokraj drugoga (npr. "[...] u kojoj su sudjelovali ljudi diljem svijeta iz preko dvjesto zemalja." "Reumatoidni artritis je autoimuna bolest kod koje, iz za sada nepoznatog razloga, imunološki sustav napada zglobove i vezivno tkivo." "[...] žamor i graja koja je dopirala iz u tom trenutku emitiranog programa." "[...] i to se iz do sada objavljenih podataka jasno vidi." "[...] da su pristigle nove do sada neevidentirane obveze iz prije nekoliko godina [...]").

\section{TVORBENA OBILJEŽJA PRIJEDLOGA S IZ- / И3-}

U gramatikama se u poglavlju o tvorbi prijedlozi obično ne obrađuju. Neke napomene o njihovoj tvorbi nalaze se uglavnom u poglavlju o morfologiji u opisu prijedloga kao vrste riječi. U tvorbi ovih prijedloga na prvome je mjestu prijedlog $i z-/ u_{3}{ }^{12}$, a na drugome je oblik koji uglavnom dolazi i sam

1 U pretrazi je u polje CQL upisan regularni izraz [word="iz"][tag="S."”], nakon čega su rezultati poredani po učestalosti.

12 "Riječ je praslavenska, usp. stslov. $i z ъ$, rus. изъ.; u zapadnijem je jezicima otpalo $i$, te glasi u češ. i poḷ. $z$ (i ze); to se dogodilo djelomice i u novoslovenskom jeziku i u kajkavskom govoru 
kao prijedlog (neki su od njih neproizvedeni, a neki se oblikom podudaraju s kojom drugom riječju):

- теđи / меж, между, промеж, промежду ${ }^{13}$

- nad/ Had $^{14}$

- nutra / нутри, внутри ${ }^{15}$

- pod/nod 16

- pred/ neped ${ }^{17}$

- sred / cpedu ${ }^{18}$

- van / вне 19 $^{19}$

- $z a / 3 a^{20}$.

a gdjegdje i u čakavskom, te se češće tad ne može razlikovati od prijedloga $s$ (s gen.), v. s i $z$.” (ARj 1880-1976: s. v. iz).

13 "Od međa nastade i veoma važan prijedlog medu (iz-) (Vuk) = mezu [...] = meju (izmeju, izmej, 15. v.), stcslav. meždu. Vokal u potječe od lokativa duala.” (Skok 1971-1974: s. v. međa). U ruskome se ispred меж, между pojavljuje još i про- koji Cyganenko opisuje kao prijedlog koji dolazi s akuzativom te potječe od indoeuropskoga *pro sa značenjem 'ispred, naprijed, pred"' (usp. Cyganenko s. v. npo-).

14 "Prijedlog ovaj imaju i drugi slav. jezici. a postao je od $n a-d$, t. j. prvi je dio prijedlog $n a$, a drugi dio - $d$ (upravo $-d b$ ) stoji po svoj prilici u svezi s prijedlogom $d o$; tako su postali i prijedlozi pod, pred (t. j. po-dz, prê-db).” (ARj 1880-1976: s. v. nad).

15 "[...] sveslav. i praslav. (stcslav.) Qtroba »intestina«, upravo pridjevski apstraktum na -oba (v.) od stcslav. pridjeva otrъ. Taj je očuvan u prilogu vъnotrě $>$ unutra $(v ъ>u$ kao u juče $<$ $v ъ c ̌ e r a)=$ unutar $=$ nutri $($ ŽK, s gubitkom vъ- kao u nük), nùtra pored nutre (Istra), iznûtra $(-e)=$ iznútra $($ Kosmet $)=$ nanutra, iznutar, iznutri (čakavci), iznutru." (Skok 1971-1974: s. v. utroba). U ruskome внутри očuvalo se $v$ kojim se potvrđuje značenje unutrašnjosti.

16 "Nalazi se u svim slavenskim jezicima. Postalo je pod od po-db, a -db je onaj isti dodatak, koji se nalazi i u nad, pred, (t. j. na-db, prê-db); ipak nije jasan razvitak značeńa prijedloga pod, jer bi se očekivalo, da će biti kakva sveza u značeńu po i pod, onako kako je između na i nad." (ARj 1880-1976: s. v. pod).

17 “[...] sveslav. i praslav. *per-db, prijedlog s ak. i instr., prilog (na)prijed, imenički i glagolski prefiks (tipovi predgovor, predsijedati) »coram, ante«. Veže se s prijedlogom iz, s ïspred sa gen. (16. v.), ispreda (Vuk), sprijeda. U tom slučaju je pridjevskog podrijetla jer je prijeda genitiv." (Skok 1971-1974: s. v. pred).

18 Sred je nastalo "od iste osnove kao imenica srijeda, sredina i sl. Po postanku bit će akuzativ sing. možda imenice muškog roda *srêdb ili ženskog roda *srêdb. [...] Mogao bi to biti i okrńeni lok. sg. srijedi (Daničić u rječniku s. v. sreda) ili akuz. sg. srijedu od imenice srijeda; ispor. prijedloge sredi i sredu s pokraćenim osnovnim samoglasnikom - $\hat{e}$ - i s reduciranim -j- iza $r$, pred kojim je drugi suglasnik." (ARj 1880-1976: s. v. sred). Prijedloge sred, isred i Skok (1971-1974) obrađuje s. v. srijeda.

19 Van je "prijedlog s gen., »extra«, složen izvan, izvam, izvanj, izvana [...] prvobitno akuzativ, stcslav. lokativ vъné)", određen kao sveslav. i praslav. (Skok 1971-1974 s. v. van²).

$20 Z a$ je "sveslav. i praslav. nenaglašeni (enklitični) prijedlog s gen. (za vremena), ak. (za vrijeme) i s instrum. (za njim), te veoma raširen i živ prefiks, imenički, glagolski i priloški. Udružuje se sa $i z$ u $i z a$, sa radi u zarad(i). [...] Kao nad, pred i pod dobiva i on već u ie. zamjenički elemenat $-d$ stcslav. zadb > zad." (Skok 1971-1974: s. v. za). 
U hrvatskome se javlja još i $k_{r a j}{ }^{21}$ i više (prijedlog s prostornim značenjem koji se pojavljuje i kao prilog, usp. Matas Ivanković 2014: 256), a u ruskome $3 a \partial u^{22}$ koji se u primjerima iz korpusa većinom pojavljuje u funkciji priloga, ali ima i primjera s funkcijom prijedloga.

Tvorbeni model prijedloga s $i z$ - mogao bi se odrediti kao prefiksalna tvorba ili srastanje. Belić (1949-1950: 101) primjerice govori o prefiksu (i prijedlogu-prefiksu) te u složenim prijedlozima iznad, ispod, ispred, između i iza razlikuje dva procesa: "Slaganje predloga-prefiksa $i z$ ablativnog značenja i nad, pod, pred, među i za akuzativno-instrumentalne upotrebe i slaganje izdvojenog od glagola prefiksa $i z$ - sa pojačajnom (komparativnom) funkcijom sa pomenutim prostim predlozima koja se takođe slaže sa ablativnim genitivom." Prema Babiću (2002: 48) za čistu prefiksalnu tvorbu karakteristično je da prefiksi dolaze na cijelu riječ i da tvorenica ostaje u istoj kategoriji u kojoj je i osnovna riječ. Poslije iz dolazi prijedlog (npr. nad), a novonastala tvorenica također je prijedlog (iznad), što se može shvatiti kao potvrda da je riječ o prefiksalnoj tvorbi. No moguća je interpretacija i da je riječ o srastanju jer se spajaju dva prijedloga (npr. iz + nad =iznad). Naime, prefiks "modificira samo leksičko značenje osnovne riječi, ali ne potire njezinu morfološku narav" (Barić i sur. 1997: 295), dok kod iznad, ispod, ispred, između i iza prvi prijedlog modificira značenje drugoga, ali istodobno drugi prijedlog gubi neka svoja obilježja, mijenja se rekcija, što pokazuje da nije riječ samo o modifikaciji leksičkog značenja, već i o promjeni gramatičkih svojstava. Oba prijedloga imaju svoju funkciju te "ravnopravno" tvore novu riječ, srastaju u novu tvorenicu. Srastanjem nastaju i drugi prijedlozi, npr. $u$ oči-uoči, i prilozi, npr. uz brdo-uzbrdo (usp. Barić i sur. 1997: 298). Pripadanje obiju sastavnica istoj vrsti riječi, pri čemu riječ koja je na drugome mjestu u nekim slučajevima gubi svoja gramatička obilježja (odabir oblika riječi iza sebe), potvrđuje da je riječ o srastanju ravnopravnih jedinica u novu riječ. Tome u prilog ide $\mathrm{i}$ usporedba hrvatskih prijedloga s prijedlozima $\mathrm{u}$ ruskome, u kojem se tvorbene jedinice i u nesastavljenom zapisu pojavljuju u jedinstvenoj prijedložnoj funkciji, jednako kao i pravopisom propisan oblik

21 "Riječ kraj može biti kao prilog i prijedlog sam i u vezi s prijedlozima na, po, sa, s-, u, uz i s pokaznom zamjenicom onkraj, krájce (Lika), kräjimice (Stulić), prekâj (Kosmet) prijedlog s gen. »pokraj« ( $r$ je ispao zbog disimilacije $r->r-\varnothing<*$ *pred kraj." (Skok 1971-1974: s. v. kraj).

22 U ruskome postoji imenica зад 'zadnji dio čega' koja se prema Cyganenko (s. v. зад) pojavljivala i u obliku задь iz kojeg su nastajali drugi oblici (usp. "Из др.-pус. предложного сочетания по зади (задь в дат. п.) возникло нареч. позади[,] сзади, за спиной”). 
sa spojnicom, regirajući riječ koja dolazi iza drugoga prijedloga (гол из вне игры = гол из-вне игры 'gol izvan igre').

\section{GRAMATIČKA OBILJEŽJA PRIJEDLOGA S IZ- / ИЗ-}

Razlika između dvaju jezika vidljiva je i u rekcijskim obilježjima prijedloga tvorenih s iz- / из-. Hrvatski prijedlozi vezuju uza se riječ u genitivu, što je zanimljivo za ispod, ispred, iza, između i iznad, jer iz dolazi s genitivom, a prijedlozi pod, pred, za, među i nad, koji su na drugome mjestu i bliže su riječi kojoj otvaraju mjesto, dolaze s akuzativom i instrumentalom, pa bi se moglo očekivati da će u tom padežu biti i riječ koja slijedi. Pritom je, prema rezultatima iz korpusa, osim uz $z a$, uz te prijedloge instrumental višestruko češći od akuzativa, što je pokazano u Tablici 3. S druge strane, u ruskome iza prijedloga tvorenih s из- dolazi genitiv, ali iza prijedloga из-между, из-над, из-перед, из-промежду može doći i instrumental, što znači da prijedlog koji je u tvorenici na drugome mjestu uvjetuje oblik (usp. instrumental iza из над u primjeru "Незадолго до этого раздался громкий хлопок, и из над головами прохожих просвистели четыре канализационных люка." "Nedugo prije toga začuo se glasan prasak, a iznad glava prolaznika zazviždala su četiri kanalizacijska poklopca."). Budući da je u hrvatskome uz prijedloge $p o d$, pred, među i nad instrumental češći od akuzativa, a u ruskome se uz genitiv iza prijedloga из-между, из-над, из-перед і из-промежду pojavljuje instrumental, u daljnjoj analizi u prvom je planu odnos genitiva $i$ instrumentala.

Tablica 3. Broj primjera u hrvatskome s akuzativom i instrumentalom iza prijedloga među, nad, pod, pred, za..$^{23}$

\begin{tabular}{lrc}
\hline & akuzativ & instrumental \\
\hline među & 12633 & 118778 \\
nad & 2009 & 121459 \\
pod & 39002 & 389767 \\
pred & 36001 & 140462 \\
za & 4434217 & 281010 \\
\hline
\end{tabular}

U pretrazi je u polje CQL upisan regularni izraz kojim se iza prijedloga tražio oblik u akuzativu odnosno instrumentalu, npr. [word="među"][tag="....a"] i [word="među"][tag="...i"]. 
Milka Ivić genitiv i instrumental određuje kao padeže konekcije čija je upotreba uvjetovana osnovnom idejom o povezivanju dviju inače posebnih pojava po nekom specifičnom odnosu. Genitiv je padež odmjeravanja jedne pojave prema drugoj, a instrumental je padež udruživanja jedne pojave s drugom. To su podjednako "padeži konekcije” i odatle je već i teorijski opravdana mogućnost da se njihova značenjska polja u pojedinim slučajevima poklope. Međutim, semantički spektar genitiva nesumnjivo je širi. Njime se određuje mjesni odnos po kriteriju blizine (npr. blizu, pored, izvan i sl.), dok se instrumentalom mogu odrediti isključivo oni prostorni položaji koji odgovaraju uspostavljanju odnosa usporednosti u funkciji dviju pojava. (usp. 1957/58: 143 i 150).

O prijedlozima tipa iznad pisao je Belić (1949-1950: 100-101) u radu o "deprefiksaciji”" te na kraju zaključuje:

da predlozi koji se stavljaju ispred drugih predloga samo onda menjaju upravljanje padežom kada u predloškom smislu menjaju značenje predloga pretvarajući ih napr. od predloga za pravac kretanja (sa akuz.) ili za mesto (sa instrum. ili lokat.) u predloge za udaljavanje (sa ablativnim genitivom) ili sl. Ali kada oni u priloškom pravcu bliže određuju predloge ne menjajući njihova predloška značenja, onda oni ne mogu menjati i njihovo upravljanje padežom. Kod srpskohrvatskih predloga iznad, ispod, ispred, između i iza - mi smo videli primenu ovoga u dva pravca, tj. i stvaranje ablativnog značenja njihova mesto akuzativnog ili instrumentalno-mesnog, sa dobivanjem konstrukcije sa ablativnim genitivom i pojačavanje komparativne nijanse kod prostih predloga nad, pod, pred, među i za, što je dalo takođe konstrukciju sa ablativnim genitivom kao kod predloga više, niže, pre, posle i sl. koji takođe stoje s tim genitivom.

U ovome opisu nije potpuno jasna uloga promjene značenja, jer kao što i sam Belić opisuje, ti prijedlozi većinom imaju primarno komparativno značenje $^{24}$ koje ne mijenja značenja prijedloga, pa ne bi moglo mijenjati ni upravljanje padežom. Proces koji je Belić opisao Stevović je razdijelio u nekoliko faza: (I) prema "Idu šumom, njivom" i sl. radi preciznijeg određivanja prostora, moglo je prvobitno biti i "Idu pod šumom, njivom”, gdje su pod, nad i sl. bili prilozi. Dakle i prilog i instrumental, svaki za sebe, ima

24 "Kao što se iz ovoga moglo videti predlozi iznad, ispred, ispod, iza, između imaju ili, bolje, mogu imati dvojako značenje: a) kod svih predloga podjednako može se konstatovati pojačajno (komparativno) značenje prostih predloga pod, za, nad, pred, među koje dopušta i prelaz ovih predloga u druga značenja (napr. pored, dalje, niže i sl.); i b) gotovo svi predlozi sastavljeni sa $i z$, neki u manjoj meri, a neki u većoj, dopuštaju i opšteablativno značenje uz predloge pod, nad, pred, među i za (tj. ne značenje predloga iz nego od)." (Belić 1949-1950: 91). 
funkciju glagolske dopune. Instrumental znači mjesto, a prije, nad i sl. mjesto i usporedbu po visini (kao gore, dolje). (II) Kako su se prilozi pred, pod poklopili sintaktički s instrumentalom, prilog je promijenio funkciju i postao prijedlog. Umjesto dvije priložne odredbe dobili smo prijedlog s padežom u lokativnoj padežnoj funkciji. Sada se gubi veza s polaznim stanjem (I) i instrumental gubi vezu s instrumentalnom funkcijom (prosekutivnom). (III) U sintaktičkoj situaciji kada se padežni oblik ne poklapa s padežnom sintaktičkom funkcijom (padežni oblik instrumental, a sintaktička funkcija lokativna), padežni nastavak postaje bespredmetan i padežni se oblik instrumentala svodi na funkciju imenice. Prijedlog naginje funkciji prefiksa. (IV) Trebalo je pojačati sintaktičku lokativnu funkciju ovih konstrukcija, njihovu adverbativnu funkciju čistoga padežnog odnosa. Potrebno je bilo tu neko sredstvo koje bi bilo čist sintaktički znak. Tome je najbolje odgovarao neki prijedlog koji je izgubio značenje i koji se sveo na sintaktički znak (funkciju). I to funkciju pojačavanja. To je bio glagolski prefiks iz-. U sastav složenih prijedloga on se prenosi u istom svojstvu (u funkciji gramatičkoj, dolazi dakle kao prefiks) i s istom pojačajnom (komparativnom) funkcijom. Dobivamo složene prijedloge s pojačajnim osnovnim značenjem mjesta. Oni su sada komparativnog značenja i uz njih je morao doći genitiv, kao i uz sve prijedloge-priloge komparativnog značenja: više njive, niže kuće i sl. (usp. Stevović 1955-1956: 231-233).

Dominacija genitiva iščitava se i iz općih opisa padeža. Jakobson (1936/1984: 109) je ruski deklinacijski sustav sa šest padeža sveo na tri dimenzije (direkcionalnost, kvantifikacija, marginalnost), a genitiv i instrumental po dvjema dimenzijama nalaze se na suprotnim stranama (genitiv je kvantifikacijski, nemarginalni, dok je instrumental nekvantifikacijski, marginalni). ${ }^{25}$

Hewson i Bubenik (2006: 51-52) navode tri razine padeža, u prvoj su nominativ i akuzativ, u drugoj genitiv i dativ, u trećoj instrumental i lokativ:

\footnotetext{
25 "If we limit the analysis of the Russian declensional system to its six primary cases, [...] then the following three dimensions, on which the system is based, emerge clearly:

The feature of directionality in the $\mathrm{A}$ and the $\mathrm{D}$ is opposed to the absence of this feature in the $\mathrm{N}$ and $\mathrm{I}$; we shall call the $\mathrm{A}$ and $\mathrm{D}$ directional cases.

The feature of quantification in the $\mathrm{G}$ is opposed to its absence in the $\mathrm{N}$ and $\mathrm{A}$, and the same feature in the $\mathrm{L}$ is opposed to its absence in the I and D; we shall call the $\mathrm{G}$ and L quantificational cases as distinct from the other non-quantificational cases $-\mathrm{N}, \mathrm{A}, \mathrm{I}$, and D.

It is the feature of marginality in the I, D, and L which opposes these cases to the $\mathrm{N}, \mathrm{A}$, and G, which lack this feature."
} 
In the case systems of IE languages, the core cases are Nominative and Accusative, which can be used in the core syntactic roles of Subject and Object, and normally do not require the intervention of any preposition in playing those roles. The roles of Possessor and Indirect Object are secondary, in that these can not normally be used as subject or object of the verb; consequently Genitive and Dative form a second level of the system of cases, an adjectival level that may also have an adverbial function. All other cases are tertiary and adverbial, and are usually the first cases to be lost when there is attrition, which is a sure sign of their tertiary ranking in the system. Loss of the adverbial cases leaves a system of four cases, Nominative, Accusative, Genitive and Dative, as in Classical Greek or the Germanic languages [...]

Prema Jakobsonu genitiv je određen kao kvantifikacijski padež, za razliku od instrumentala koji nema to obilježje. Instrumental je marginalni padež, što se podudara i s opisom Hewsona i Bubenika da instrumental spada u tercijarne padeže koji se najlakše gube. Iz svega se iščitava prevladavanje genitiva u odnosu na instrumental koje dolazi do izražaja i u prijedlozima s iz-, uz koje se pojavljuje genitiv iako bi se mogao očekivati instrumental (ili eventualno akuzativ). Opća je padežna funkcija genitiva povezivanje, što je potvrđeno i u primjeru ponad, u kojemu se nijedan od sastavnih prijedloga ne slaže s genitivom, a iza ponad dolazi upravo genitiv. Prema Stevoviću (1955-1956: 233) "genitiv dolazi uvek u slučajevima složenog predloga, i to zbog toga što su oni priloške prirode, hibridi priloško-predloški. Genitiv je ovde u opštoj padežnoj funkciji (čist padežni odnos - nominalna pretstava u zavisnoj funkciji) i sintaksički ide uz složeni predlog koji ima funkciju zavisnog člana."

\section{ZAKLJUČAK}

U ovom radu hrvatski prijedlozi s iz- kao prvom sastavnicom (iskraj, ispod, ispred, isred, iza, između, iznad, iznutra, izvan, izviše) uspoređeni su s ruskim prijedlozima toga tipa. U ruskim općim izvorima mogu se naći samo tri takva prijedloga, od koji su из-за i из-nод u skladu s pravopisom predviđenim zapisom, dok je u Ožegovu natuknica изнутри, zabilježena bez spojnice, na drugome mjestu određena i kao prijedlog. Ostali prijedlozi (извне, извнутри, иззади, из-меж, из-между, из-над, из-перед, из-промеж, из-промежду, из среди) zabilježeni su u novijim lingvističkim istraživanjima Vsevolodove, Kukuškine i Polikarpova, i to s različitim zapisom - sa spojnicom, sastavljeno i rastavljeno - onako kako su ih autori našli na internetu, odnosno, kako i sami kažu, u realnoj upotrebi. Internet, a pogotovo mrežni korpus, koji 
zahvaljujući tome što je lematiziran olakšava ciljanu pretragu, omogućuje da se istraže pojave koje do sada nisu bile istraživane bilo zbog toga što su rijetke, bilo zbog toga što je riječ o jezičnim inovacijama.

Pronalaženje sličnosti u popisima prijedloga dvaju jezika pokazalo je da isred i iznutra, koji se obično ne navode kao prijedlozi u hrvatskim izvorima, mogu iza sebe imati riječ u genitivu te imaju obilježja prijedloga. Ruski иззади nema hrvatskog ekvivalenta, kao što ni hrvatski iskraj i izviše nemaju ekvivalenta u ruskome. U odnosu na hrvatski između ruski ima više oblika: из-меж, из-между, из-промеж, из-промежду, a hrvatskom iznutra odgovaraju dva ruska prijedloga: изнутри, извнутри.

Osim tvorbenog modela, koji je dao vrlo slične rezultate u obama jezicima, između njih postoje i razlike, primjerice u gramatičkim obilježjima. U ruskome iza prijedloga tvorenih s $и з$ - dolazi genitiv, ali iza nekih od njih (из-между, из-над, из-перед, из-промежду) mоžе doći i instrumental, što se može promatrati kao faza u kojoj genitiv još nije nadjačao instrumental. U hrvatskome je iza prijedloga s $i z$ - uvijek genitiv, pri čemu se kod prijedloga ispod, ispred, iza, između, iznad rekcija drugog prijedloga (instrumentalna ili akuzativna) povukla pred genitivnom. Tako i u prijedlogu ponad nijedan od sastavnih prijedloga ne ide s genitivom, a iza ponad dolazi upravo genitiv. Kao padež povezivanja genitiv je ovdje preuzeo dominantnu funkciju. To se može protumačiti općom dominacijom genitiva koji se u literaturi određuje kao padež povezivanja sa širokim semantičkim potencijalom, kao nemarginalni padež koji je na drugoj razini padežnog sustava, za razliku od primjerice instrumentala koji je tercijarni padež te se lakše gubi, kao što se vidi u germanskim jezicima koji su sačuvali četveropadežni sustav. Tako se i kod hrvatskih prijedloga s $i z$ - padež drugog prijedloga u tvorenici povukao pred genitivom.

\section{LITERATURA}

Anić, Vladimir. 2003. Veliki rječnik hrvatskoga jezika. Zagreb: Novi Liber.

$\mathrm{ARj}=$ Rječnik hrvatskoga ili srpskoga jezika. 1880-1976. I-XXIII. Zagreb: JAZU.

Babić, Stjepan. 2002. Tvorba riječi u hrvatskome književnome jeziku. Zagreb: Hrvatska akademija znanosti i umjetnosti; Nakladni zavod Globus.

Barić, Eugenija i sur. ${ }^{2} 1997$. Hrvatska gramatika. Zagreb: Školska knjiga.

Belić, Aleksandar. 1949-1950. "Deprefiksacija" u slovenskim jezicima (predlozi tipa iznad i slični pojavi). "Južnoslovenski filolog" 18, 87-101.

Cyganenko = Цыганенко, Галина Павловна. 1989. Этимологический словарь русского языка. Kijev: Издательство Радянська школа. http://www.slovorod.ru/ etym-cyganenko/index.html (pristupljeno 30. 11. 2017). 
Hewson, John i Vit Bubenik. 2006. From Case to Adposition: The development of configurational syntax in Indo-European languages. Amsterdam/Philadelphia: John Benjamins publishing company.

HJP = Hrvatski jezični portal. http://hjp.znanje.hr/ (pristupljeno 26. studenoga 2017).

Hrvatski pravopis. [ur. Željko Jozić i sur.]. 2013. Zagreb: Institut za hrvatski jezik i jezikoslovlje.

Ivić, Milka. 1957-1958. Sistem predloških konstrukcija u srpskohrvatskom jeziku. "Južnoslovenski filolog", 21, 141-166.

Jakobson, Roman. 1936/1984. Contribution to the general theory of case: general meanings of the Russian cases. Russian and Slavic Grammar: Studies 1931-1981. [ur. Linda R. Waugh i Morris Halle]. Berlin - New York-Amsterdam: Mouton Publishers. 59-105.

Kratka ruska gramatika = Краткая русская грамматика. 2002. [ur. Наталия Юльевна Шведова і Владимир Владимирович Лопатин]. http://www.slovari.ru/default. aspx?p=168 (pristupljeno 4. veljače 2018).

Kuznjecov = Большой толковый словарь русского языка. 2014. [ur. Сергей Александрович Кузнецов]. http://gramota.ru/slovari/info/bts/ (pristupljeno 27. studenoga 2017).

Matas Ivanković, Ivana. 2014. Izražavanje prostora i vremena prijedlozima s genitivom u hrvatskom i ruskom jeziku. Zagreb: Institut za hrvatski jezik i jezikoslovlje.

Ožegov = Ожегов, Сергей Иванович, Шведова, Наталия Юльевна. 1993. Толковый словарь Ожегова онлайн. http://slovarozhegova.ru/ (pristupljeno 27. studenoga 2017).

Poljanec, Radoslav Franjo. 2013. Ruska gramatika za svakoga. Zagreb: Školska knjiga.

Raguž, Dragutin. 1997. Praktična hrvatska gramatika. Zagreb: Medicinska naklada.

RHJ = Šonje, Jure [ur.]. 2000. Rječnik hrvatskoga jezika. Zagreb: Leksikografski zavod "Miroslav Krleža" i Školska knjiga.

Rozentalj = Розенталь, Дитмар Эльяшевич. 1997. Справочник по правописанию и стилистике. http://rosental-book.ru/ (pristupljeno 17. studenoga 2017).

Ruska gramatika = Русская грамматика. 1982. [ur. Наталия Юльевна Шведова i sur.]. Moskva: Академия наук.

Silić, Josip i Ivo Pranjković. 2005. Gramatika hrvatskoga jezika za gimnazije $i$ visoka učilišta. Zagreb: Školska knjiga.

Skok, Petar. 1971-1974. Etimologijski rječnik hrvatskoga ili srpskoga jezika. Zagreb: JAZU.

Stevović, Igrutin. 1955-1956. O pitanju konstrukcija padeža s predlozima. “Južnoslovenski filolog", 21, 215-235.

VRH = Jojić, Ljiljana [ur.]. 2015. Veliki rječnik hrvatskoga standardnog jezika. Zagreb: Školska knjiga.

Vsevolodova, Kukuškina i Polikarpov = Всеволодова, Майя Владимировна; Кукушкина, Ольга Владимировна; Поликарпов, Анатолий Анатольевич. 2014. Русские предлоги и средства предложного типа. Материаль к функииональнограмматическому описанию реального употребления. Moskva: Книжний дом “ЛИБРОКОМ". 


\section{SUMMARY}

\section{PREPOSITIONS FORMED WITH IZ- / И3- IN CROATIAN AND RUSSIAN}

This paper deals with Croatian and Russian prepositions consisting of two prepositions, with $i z-$ / из- at the beginning of the word. In Croatian, these are iskraj, ispod, ispred, isred, iza, između, iznad, iznutra, izvan, izviše. The list of such prepositions taken from Russian grammars and dictionaries ( $и з-3 a$ and $u 3-n о \partial)$ is expanded in the book of Vsevolodova, Kukushkina and Polikarpov, which is devoted to prepositions and includes also извне, извнутри, иззади, из-меж, из-между, из-над, изнутри, из-перед, из-промеж, из-промежду, из среди. This type of prepositions has not been described previously. They differ in writing, but also in grammatical features. Prepositions from that list are compared with Croatian prepositions in orthography, word-formation and grammatical features.

Key words: prepositions, Croatian, Russian, genitive, instrumental 